\title{
ANALYSIS OF THE DEVELOPMENT OF A HYDROLOGICAL BALANCE FOR FUTURE DECADES IN THE SENIANSKA DEPRESSION IN THE EASTERN SLOVAK LOWLAND
}

\begin{abstract}
The goal of the article was to analyze the hydrological balance for future decades in a pilot area in the Eastern Slovak lowland. The aim was to set up the physically-based Mike SHE hydrological model for the modeling hydrological balance in the selected wetland ecosystem in the Eastern Slovak Lowland. The pilot area - the Senianska depression is located near the village of Senne, between the Laborec and Uh Rivers. Specifically, it is a traditional landscape of meadows, marshes, cultivated soil, small water control structures and forests. To get a complete model set up for simulating elements of the hydrologic balance in the pilot area, it was necessary to devise a model for a larger area, which includes the pilot area - the Senianska depression. Therefore, both the Mike SHE model was set up for the Laborec River basin (a model domain of $500 x$ $500 \mathrm{~m}$ ) and the Cierna voda River basin (a model domain of $100 \times 100 \mathrm{~m}$ ), for the simulation period of 1981-2007, is order to get the boundary conditions (overland flow depth, water levels, discharges and groundwater table) for the model of the pilot area. The Mike SHE model constructed for the pilot area - the Senianska depression (a model domain of $1 \times 1 \mathrm{~m}$ ) -was used to simulate the elements of the hydrological balance for the existing conditions during the simulation period of 1983-2007 and for climate scenarios for the simulation period of 19832100. The results of the simulated elements of the hydrological balance for the existing conditions were used for a comparison of the evolution of the hydrologic conditions in the past, for identifying wet and flooded areas and for identifying the spatial distribution of the actual evapotranspiration in the pilot area. The built-up model with setting values was used for modeling the hydrological balance in changed conditions - climate change.
\end{abstract}

\section{INTRODUCTION}

Wetlands are considered to be the most biologically diverse of all ecosystems. Preservation of their biodiversity and sustainable development of the landscape is especially important. Today, the existence of wetlands in Slovakia is in danger because of their degradation caused by improper and insufficient management, their drying out or anthropogenic influences on the landscape. The

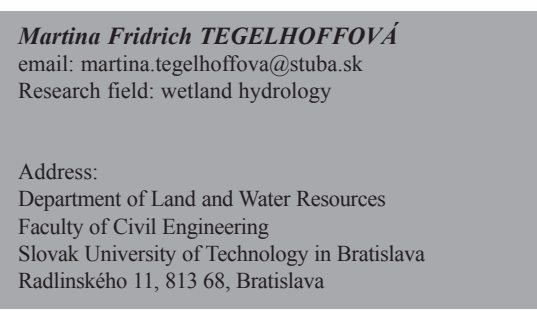

KEY WORDS

- Hydrological modeling,

- Mike SHE model,

- wetlands. 


\section{SIOYJYSOOUSSILAL \\ Of $\mathrm{f}^{*}$

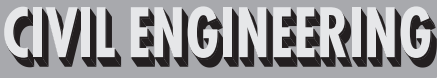

2010/4 PAGES $30-40$

The aim of this article is to find out if the climate change (decreasing of the air temperature and increasing of the rainfall) will have an impact on total hydrological balance of the simulated area. This is interesting for us from the point of the possibilities of restoration of the Čierna voda wetland. This was done as a part of the Laborec Uh project, which is presently continuing. The project contributes to the mainstreaming of integrated ecosystem management principles and practices into the land and water management and agricultural sectors. We used the Mike SHE hydrological model for modeling the hydrological balance in wetland systems for existing and changed conditions - climate change. The modeling area - the Senianska depression is located near the village of Senne, between the Laborec and Uh Rivers in the Eastern Slovak lowland. Specifically it is an area with a traditional landscape of meadows, marshes, cultivated soil, small water control structures and forests.

Due to the large amount of results from the modeling, not all of them can be presented here. In the article we are focusing on a comparison of the overland flow and actual evapotranspiration for existing and changed conditions. There are more results possible from the simulations such as the groundwater table, soil moisture, discharges and water levels in the rivers, etc.

\section{WETLAND HYDROLOGY}

Wetlands belong among the most productive ecosystems in the world. They are important for water management function, decreasing flood impacts, trapping sediments, cleaning impure water, climate stabilization in an area and recreation (Juráková, Skalová, 2005). Wetlands have been defined by Cowardin, et al. (1979) as: "Lands transitional between terrestrial and aquatic systems where the water table is usually at or near the surface or the land is covered by shallow water. Cowardin also stated that wetlands have one or more of the following attributes: 1.) at least periodically, the land predominantly supports hydrophytes; 2.) the substrate is predominantly undrained hydric soils; and 3.) the substrate is a nonsoil and is saturated with water or covered by shallow water at some time during the growing season of each year (Cowardin, et al., 1979). The protection of wetland functions and attributes is not possible without knowing wetland hydrology (Mitsch, Gosselink, 2000). Wetland hydrology is determined by a number of different site characteristics, which include: amount of precipitation, evapotranspiration, runoff, groundwater inflow, proximity to streams, topographic position, soil permeability, and plant cover (Environmental Laboratory, 1987). All of these factors determine the frequency and duration of soil saturation or inundation (Environmental Laboratory, 1987). The individual character of wetland and river basin interactions has a significant impact, so it is complicated to determine the hydrological balance and hydrological functions of different types of wetlands (Carter, 1986).

Many hydrological models have been used for wetland hydrology analysis. They are used as a modeling tool for solving problems, predicting floods in the future, modeling past floods, estimating landuse change impacts (deforestation, reforestation, urbanization, agricultural changes), building new water control structures, river flow regulations and operating rules, changes in water control structures, modeling the impact of climate changes, etc. The Mike SHE hydrological model is used for modeling the hydrological balance in a defined area (the Senianska depression) for the existing and changed conditions.

\section{APPLICATION OF THE MIKE SHE MODEL}

The Mike SHE is an integrated hydrological modeling system which covers the entire land phase of a hydrological cycle. Thus Mike SHE is not just a three-dimensional, numerical groundwater model, but also includes numerical models for overland flow, unsaturated flow, solute transport, agricultural practice, evapotranspiration, etc. Mike SHE is by default coupled to Mike 11 (DHI, 2008). MIKE SHE offers numerous process descriptions that can be used in various combinations, depending on their scope; it is ideal for distributed rainfall-runoff modeling. Mike SHE can simulate the processes of a hydrologic cycle such as actual evapotranspiration, overland flow, unsaturated flow, the groundwater table and their interactions. The model includes a geographic-information system tool (ArcMap, ArcView), with which it is possible to prepare input data and process the outputs.

\subsection{Modeling area description}

The modeling area is displayed in Figure 1. The Mike SHE hydrological model was set up for 3 modeling areas - the Laborec River basin, the Čierna voda River basin and the pilot area - the Sennianska depression. We simulated the hydrological balance for the existing and changed conditions.

The village of Senne and its surrounding area belongs to a large flatland, where the elevation is from 99.26 to $102.18 \mathrm{~m}$ a.s.l.; and it is situated in the Eastern Slovak Lowland (Repka, 1961).

\section{Geology and hydrogeology}

The Senianska depression is a large natural depression situated in the central part of the Eastern Slovak lowland. It is characterized by geologic heterogenity.

Neogen and quarternary sediments participate in the geology of this area. The depression is affected by quarternary alluviums from the Čierna voda River. 


\section{SIOYAUSOOUSSIAL \\ 0)

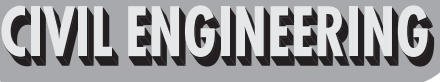

2010/4 PAGES $30-40$
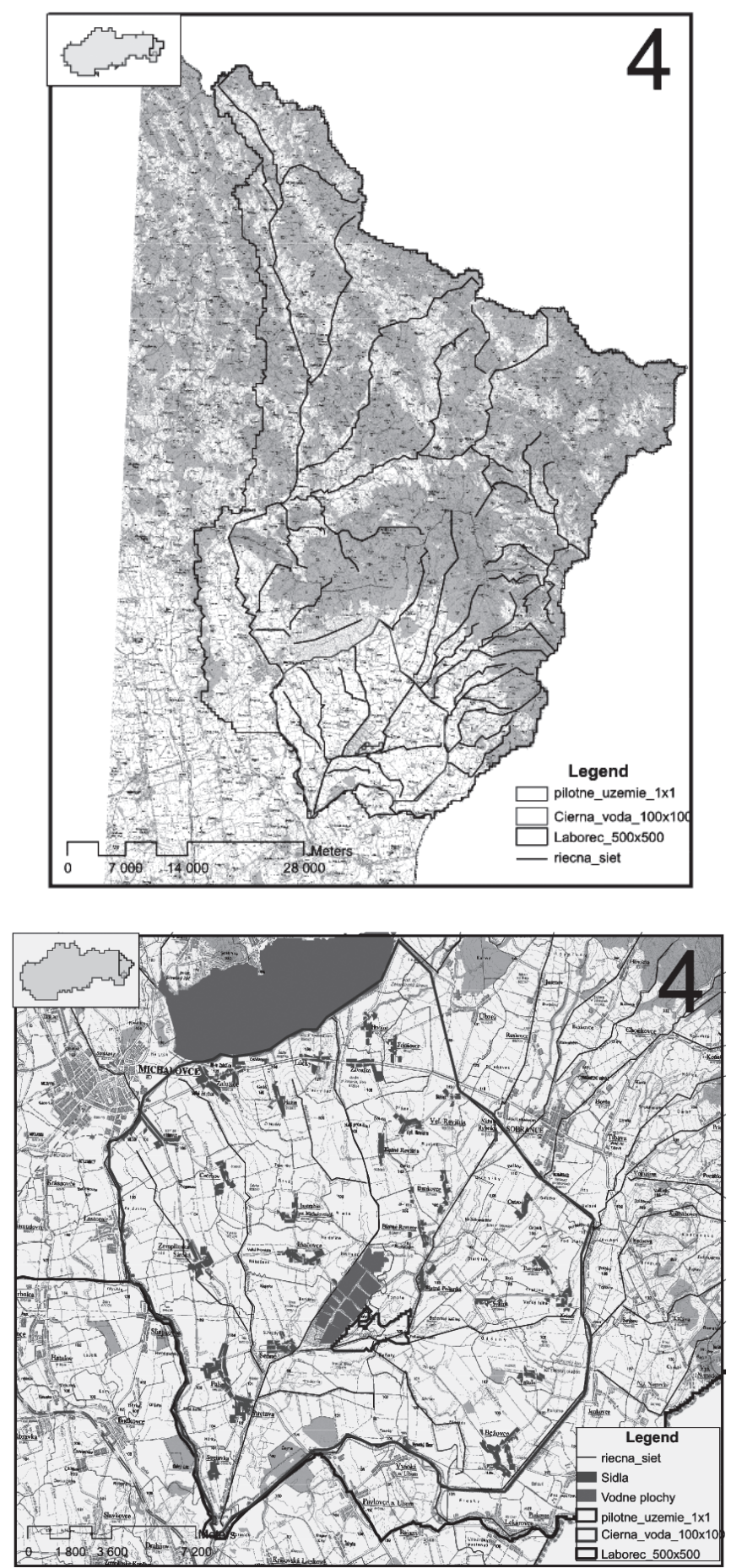

Fig. 1 The modeling area - the Laborec River basin, the Cierna voda River basin and the Senianska depression
Geologically, the Eastern Slovak Lowland belongs to the Neogenepannonian basin. Quarternary sediments are at the confluence of 3 rivers - the Laborec, Čierna voda and Uh. Those sediments are fine-grained and sometimes strongly agglutinated with clay. In some places clayey sands predominate. Besides sand, the second most typical sediments are clays. These sediments are sandy in some places and strongly agglutinated in others, but they are quite strong and plastic (Repka, 1961).

The hydrogeology of the area is based on its geology. Neogene sediments do not provide great conditions for the presence of groundwater. Only permeable sediments of sands, gravels and tufits provide a friendly environment for the presence of groundwater. The permeability of these sediments is dependent on their surface extension and whether groundwater can be supplemented by the infiltration of rainfall or surface flows (Repka, 1961).

\section{Hydrology}

According to its climate, the modeling area belongs to a warm, slightly dry area with a cold winter. The average annual air temperature in this area is from +8 to $+9{ }^{\circ} \mathrm{C}$ (Š́tor, et al., 1995).

The Senianska depression is situated in the Bodrog River basin. Bodrog is a complex river system composed of 4 main rivers (Latorica, Laborec, Uh, Ondava) that meet in a small space, which has a negative impact on the formation of large water and flood situations in this area.

The main river passing through the Senianska depression is the Okna River, which flows to the Čierna voda River. There are small sections of 2 other streams in the pilot area, which flow into the Okna River, the Hrabovsky channel and the Olsinsky channel.

\subsection{Input data}

Following characteristics were selected as input data for modeling the hydrological balance: the hydrologic and climate data (rainfall, air temperature, potential evapotranspiration), data from gauging stations and groundwater piezometers (discharges, water levels and ground water levels) and also the distributed layers of the physicalgeographical properties and characteristics of the area. We collected data on the discharges and water levels from 12 stream-gauge stations and the daily precipitation rates from 50 rainfall stations and 6 climate stations situated in the Laborec River basin (figure 2). The time series data were distributed in space using Thiessen polygons (figure 3). For calculating the daily potential evapotranspiration (PET) at each climate station, the average daily air temperature for the simulation period 1981-2007 was used. The PET was calculated using the Blaney - Criddle method, depending on the average daily PET, average daily air temperature and glare index at a particular climate station. The glare index was calculated based on a digital 


\section{IDYHUSOOUSSLAL \\ 0)

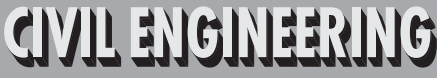

2010/4 PAGES $30-40$

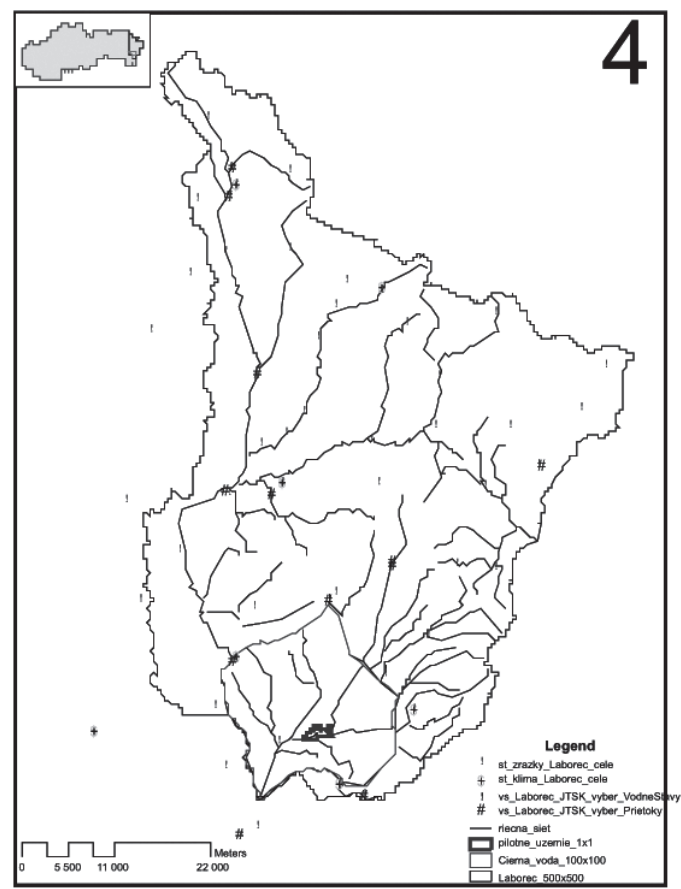

Fig. 2 Climate, rainfall, stream-gauging stations in Laborec River basin

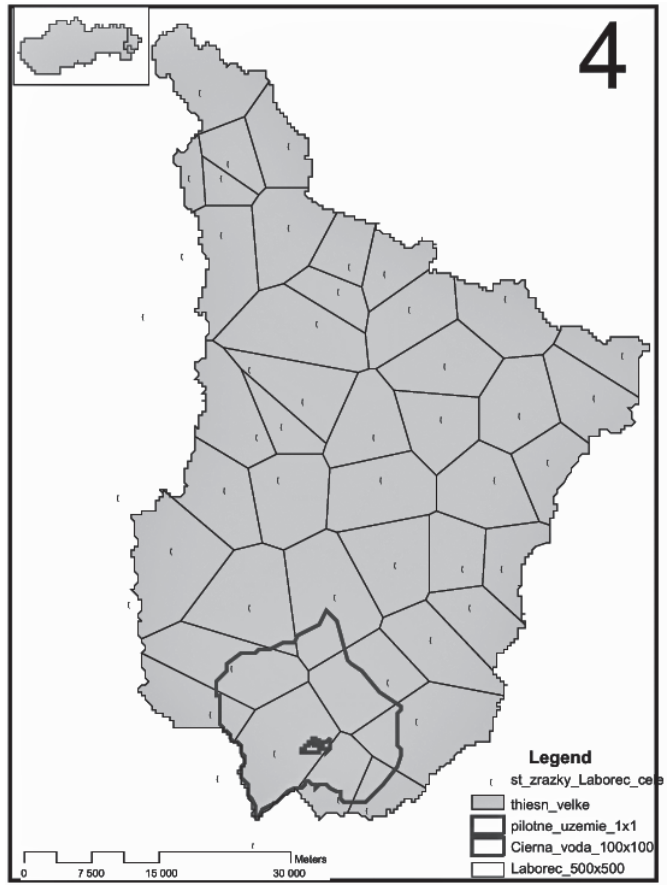

Fig. 3 Thiessen polygons in Laborec River basin elevation model as a percentage of the glare index at a particular site in particular day and the overall annual glare index.

Distributed layers of the physical-geographical properties and characteristics of the area were also used as input data:

a.) Digital model elevation:

- DEM with a 100x100 meters grid size for the Laborec River basin model,

- DEM with a 10x10 meters grid size for the Čierna voda River basin model,

- DEM with a $1 \mathrm{x} 1$ meter grid size for the Senianska depression model (figure 4).

\section{b.) Soil map:}

The soil map for the Čierna voda River basin is displayed in figure 5. The parameters of each soil type were directly assigned to the Mike SHE model:

- water content of the wilting point,

- water content of the field capacity,

- water content at saturation,

- saturated hydraulic conductivity.

c.) Land use map:

The land use map for the Čierna voda River basin is displayed in figure 6. The parameters of each land use type were directly assigned to the Mike SHE model:

- LAI (leaf area index),

- root (root depth)

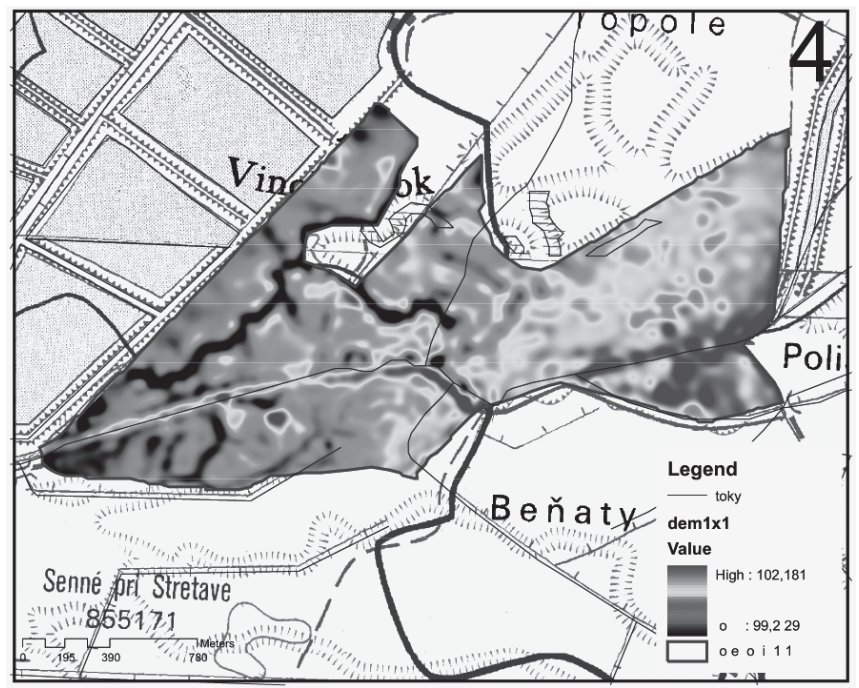

Fig. 4 DEM with a $1 x 1$ meter grid size for the Senianska depression model 


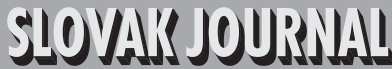 \\ 0) \\ (d)}

2010/4 PAGES $30-40$

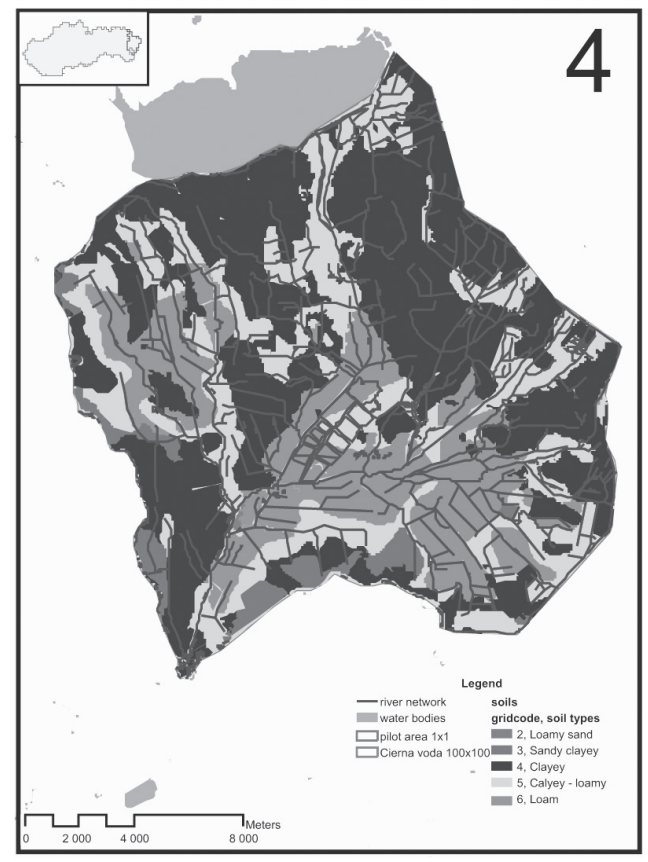

Fig. 5 Soil map

\section{d.) Overland flow parameters}

To set up the Mike SHE model and to simulate the overland flow, it is necessary to define the following parameters:

- Manning's number $\mathrm{M}\left[\mathrm{m}^{1 / 3} \cdot \mathrm{s}^{-1}\right]$, which is equivalent to the Stickler roughness coefficient,

- detention storage [mm], which is related to the amount of water stored in a local depression on a ground surface, which must be filled before water can flow laterally to an adjacent cell.

These parameters are tabular values, which directly depend on land use type.

\section{e.) Geology}

The following are the data for geological layers.

- lower level of geological layers [m],

- horizontal hydraulic conductivity $\left[\mathrm{m} \cdot \mathrm{s}^{-1}\right]$,

- vertical hydraulic conductivity $\left[\mathrm{m} \cdot \mathrm{s}^{-1}\right]$,

- specific yield [-],

- specific storage [-].

f.) River network - Mike 11 hydraulic model

Mike 11 is the hydraulic part of the Mike SHE model, which is known as the interconnection of the groundwater with surface water. The Mike 11 model was set up individually for:

- the model of the Laborec River basin,

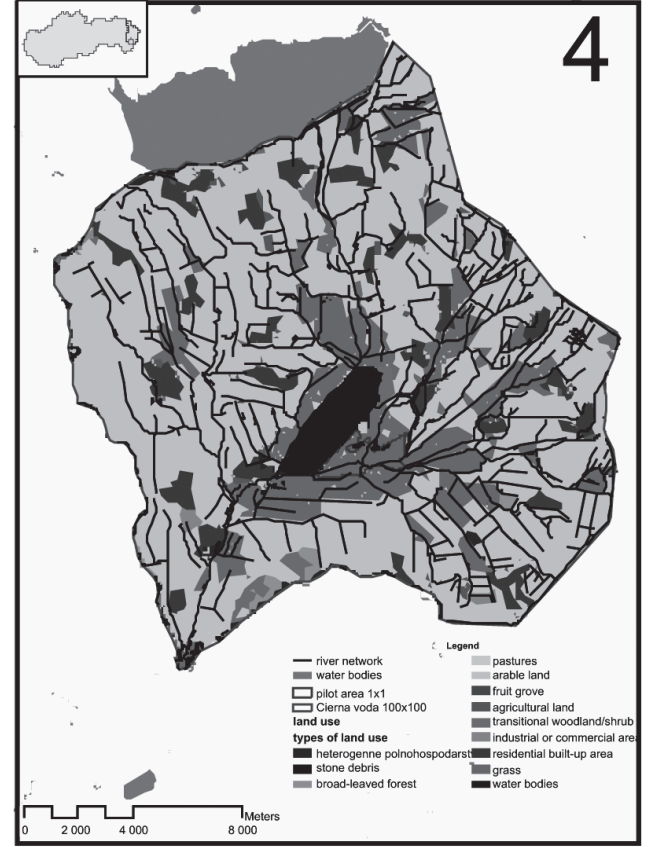

Fig. 6 Land use map

- the model of the Čierna voda River basin,

- the model of the Senianska depression.

\subsection{Model set up}

\subsubsection{Existing conditions}

The Mike SHE model was set up for:

- the Laborec catchment with a grid size of 500x500 meters,

- the Čierna voda catchment with a grid size of 100x100 meters,

- the pilot area - the Senianska depression - situated in the Čierna voda catchment with a grid size of $1 \mathrm{x} 1$ meter.

To get a complete model set up for simulating the elements of the hydrologic balance in the pilot area, it was necessary to set up a model for a larger area, which includes the pilot region. Therefore the Mike SHE model was set up for the Laborec River basin (a model domain of $500 \times 500 \mathrm{~m}$ ) and the Čierna voda River basin (a model domain of $100 \times 100 \mathrm{~m}$ ); both were set up for the simulation period of 1981-2007 to get the boundary conditions (overland flow depth, water levels, discharges and groundwater table) for the model of the Senianska depression. The built-up Mike SHE model for the Senianska depression (a model domain of $1 \times 1 \mathrm{~m}$ ) was used for simulating the elements of the hydrological balance for the existing conditions for the simulation period of 1983-2007 and for climate scenarios for the simulation period of 1983-2100. 


\section{IDYHUSOOUSSLAL \\ 0)

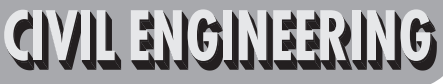

2010/4 PAGES 30 - 40

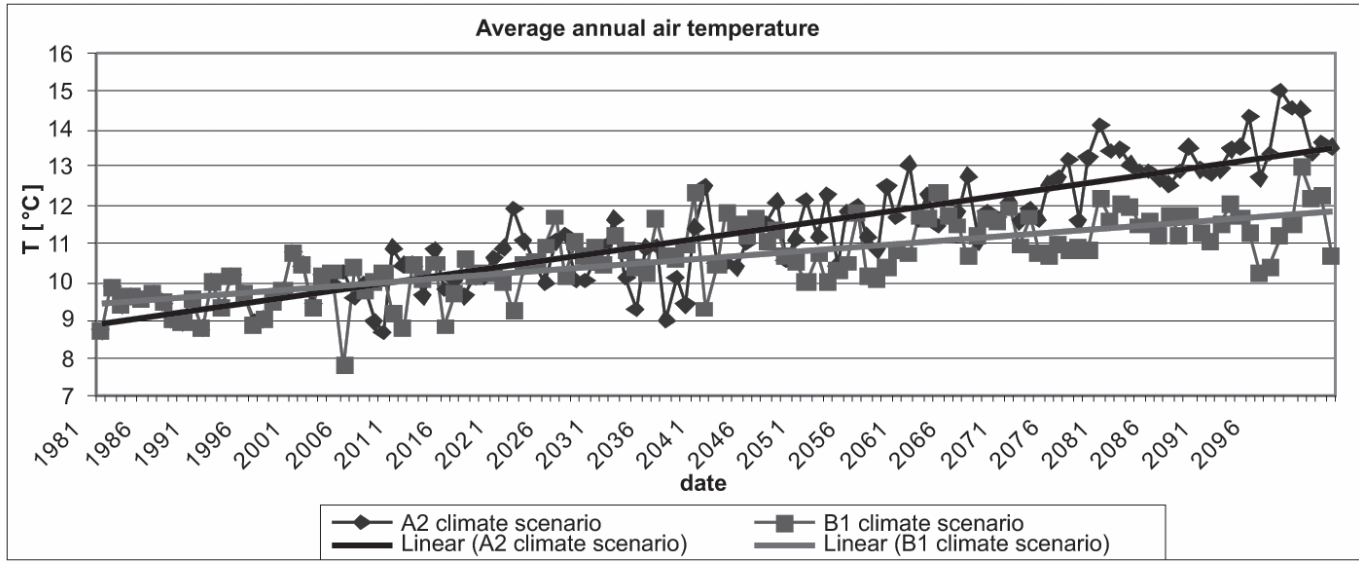

Fig. 7 Average annual air temperature $\left(T\left[{ }^{\circ} \mathrm{C}\right]\right)$ for the A2 49-22 and SRES B1 49-22 climate scenarios for 1981 - 2100

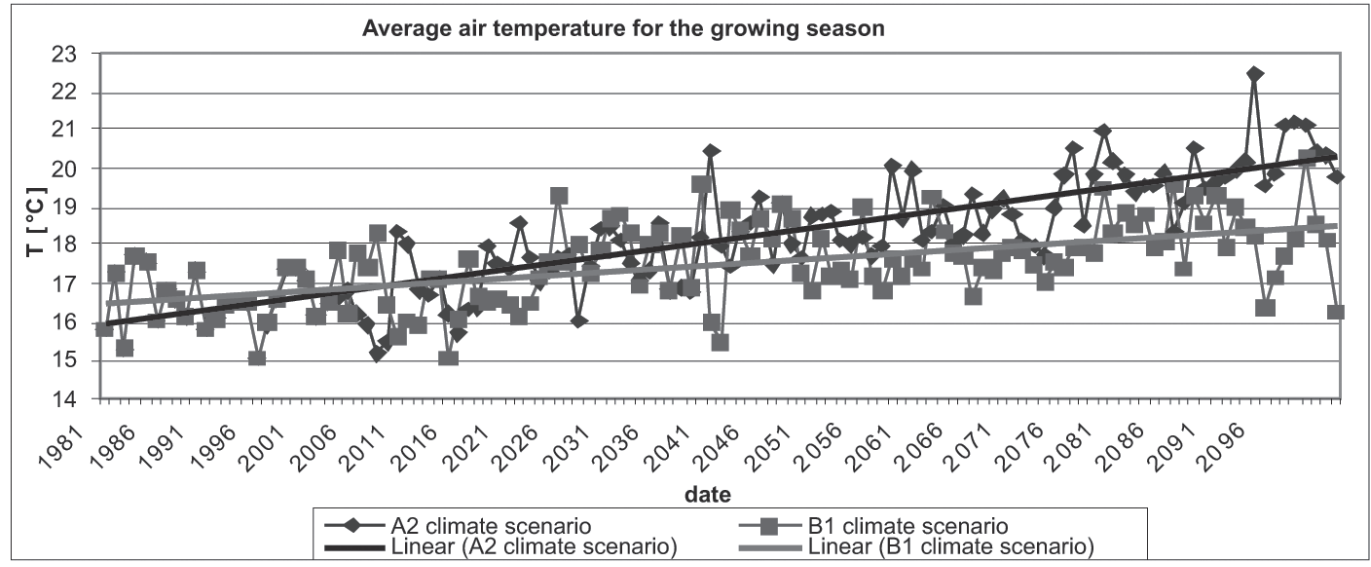

Fig. 8 Average air temperature for the growing season $\left(T\left[{ }^{\circ} \mathrm{C}\right]\right)$ for the A2 49-22 and SRES B1 49-22 climate scenarios for $1981-2100$

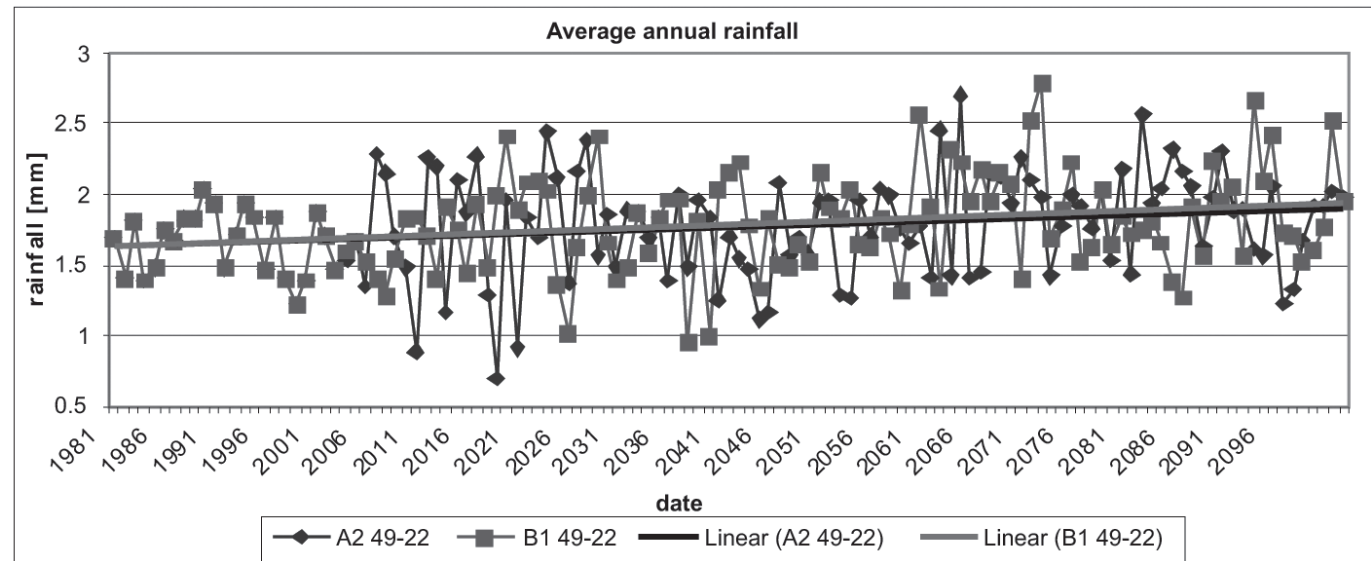

Fig. 9 Average annual rainfall in mm for the A2 49-22 and SRES B1 49-22 climate scenarios for 1981 - 2100 


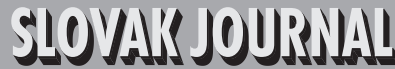 \\ 0.

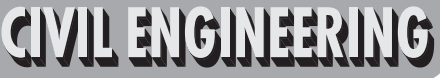

2010/4 PAGES $30-40$

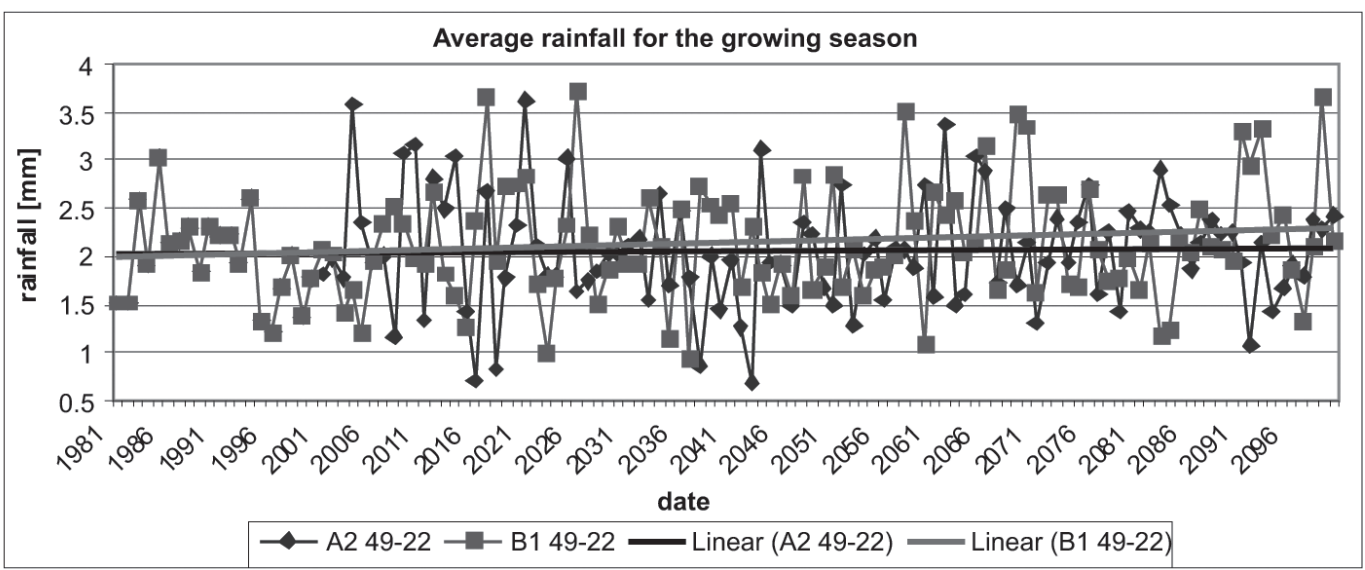

Fig. 10 Average rainfall for the growing season in mm for the A2 49-22 and SRES B1 49-22 climate scenarios for 1981 - 2100

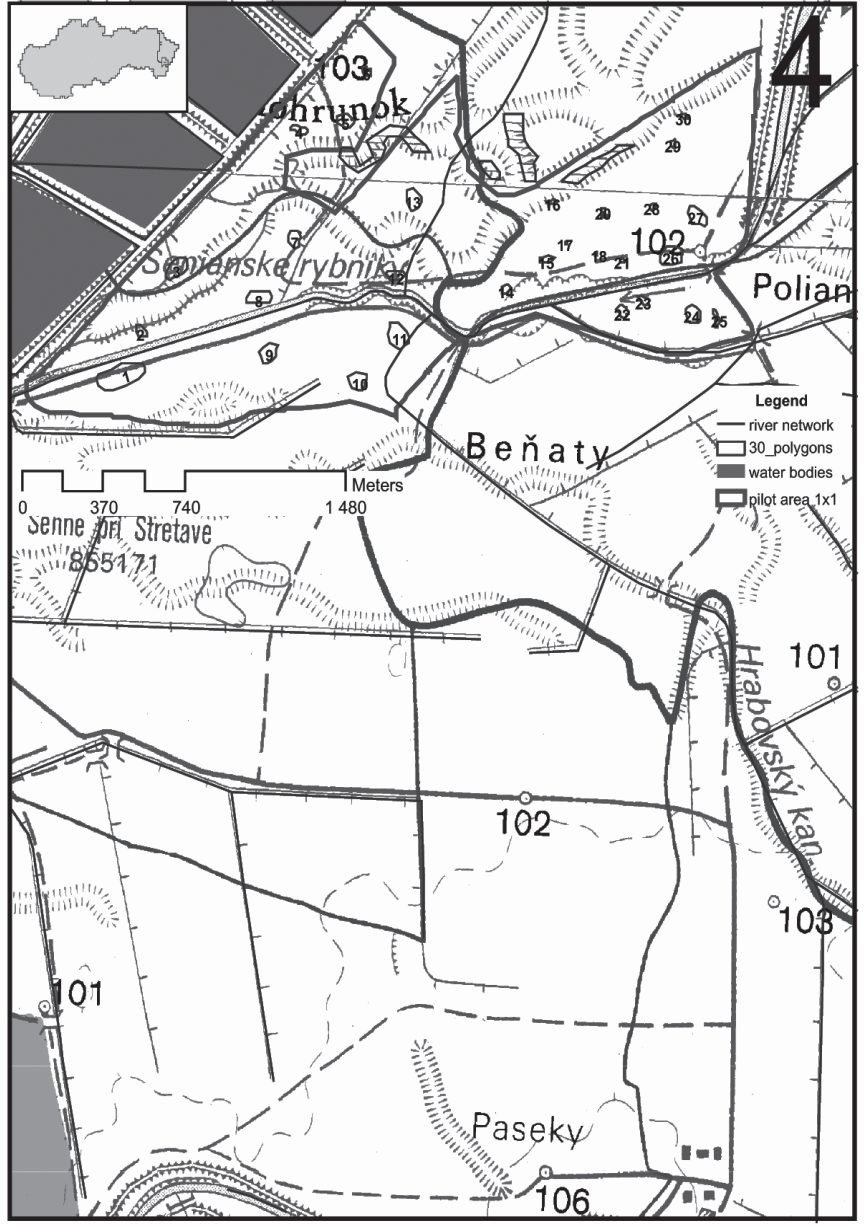

Fig. 11 Selected 30 polygons located in Senianska depression

\subsubsection{Changed condition - climate scenarios}

The built-up physically-based Mike SHE hydrological model was used for modeling the hydrological balance of the Senianska depression by considering the climatic change scenarios for future decades. The scenarios of possible trends in daily rainfall and the average daily air temperature were processed based on the outputs of the CGCM3.1 climatic model, which is the newest version of the Canadian atmosphere and ocean circulation model (Lapin, et al., 2006). The regional modification of the scenarios for the climatic stations in the Laborec River basin was developed at the Department of Astronomy and Astrophysics FMFI UK in Bratislava, based on the methodology published in Lapin, et al. (2006). Two emission scenarios - the SRES A2 and the SRES B1 - were used. The first one presents a pessimistic assumption of human behaviour till the year 2100 and the other is optimistic. These scenarios were processed for the nearest climatic station (Vysoká nad Uhom) to the Sennianska depression.

The following figures compare the average annual air temperature $\left(\mathrm{T}\left[{ }^{\circ} \mathrm{C}\right]\right)$ (figure 7) and the average air temperature for the growing season $\left(\mathrm{T}\left[{ }^{\circ} \mathrm{C}\right]\right.$ ) (figure 8) for the A2 49-22 and SRES B1 49-22 climate scenarios for the years $1981-2100$. In figures 9 and 10 the average annual rainfall in $\mathrm{mm}$ and average rainfall in $\mathrm{mm}$ for the growing season for the same scenarios are compared.

\section{OUTPUTS}

The aim of the article is to analyze the hydrological balance in the Senianska depression for the existing conditions and determine what the impact of climate change in the future will be in this area. We present the outputs - a comparison of the overland flow and actual evapotranspiration for the existing and changed conditions. In the article we provide outputs for the SRES A2 pessimistic scenario. 


\section{IDYHUSOOUSSLAL \\ of

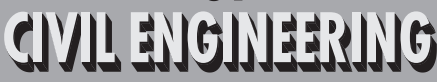

2010/4 PAGES $30-40$

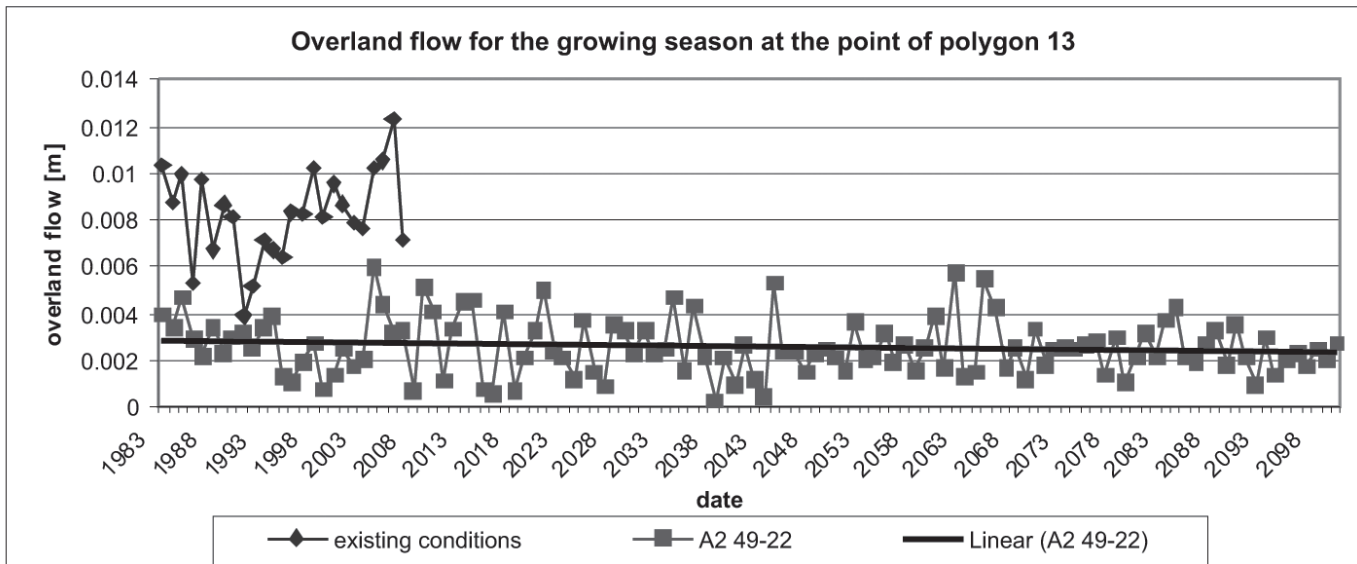

Fig. 12 Overland flow for the growing season of the entire simulated period 1983-2100

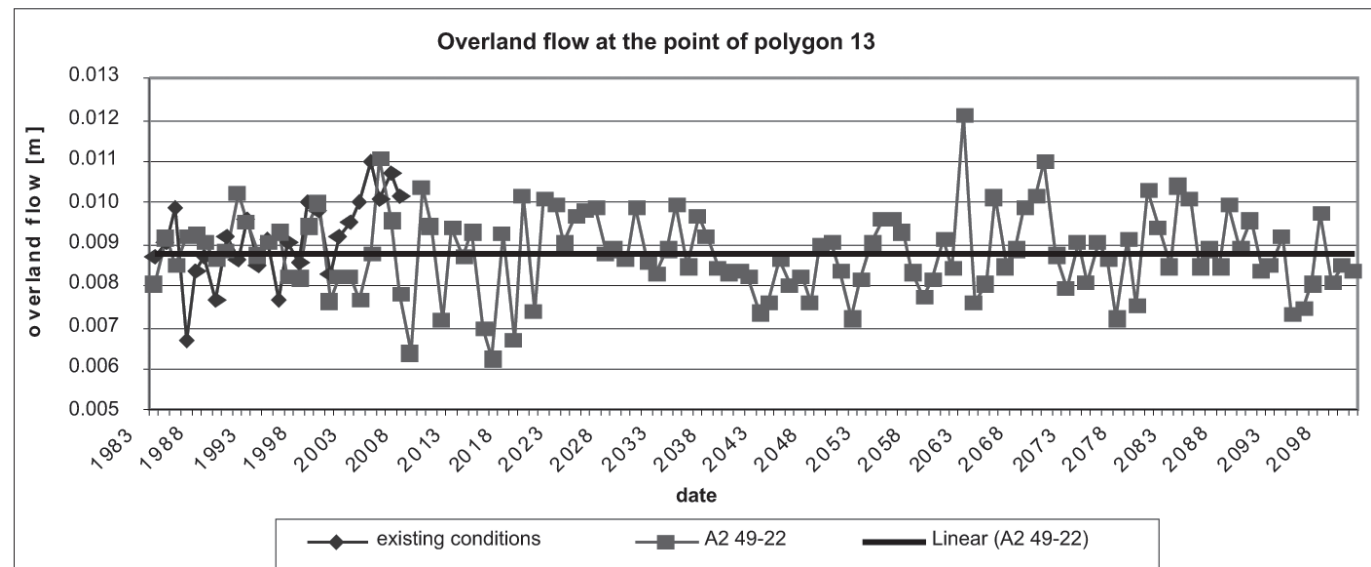

Fig. 13 Annual overland flow of the entire simulated period 1983-2100

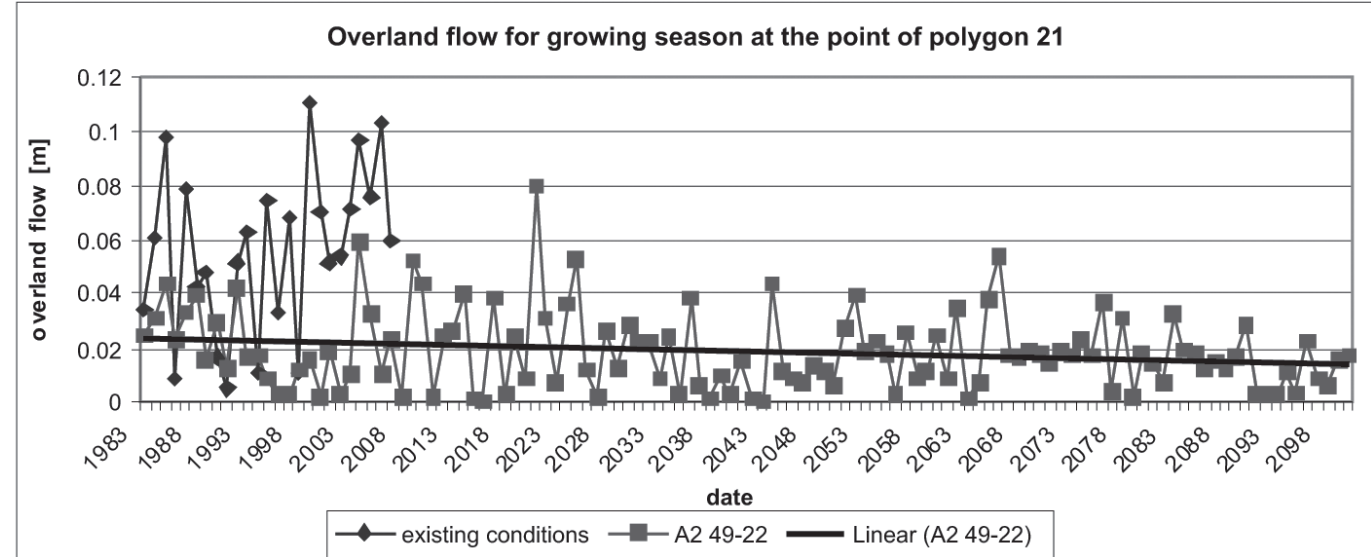

Fig. 14 Overland flow for the growing season of the entire simulated period 1983-2100 


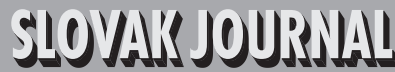 \\ 0.

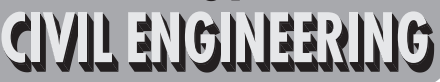

2010/4 PAGES $30-40$

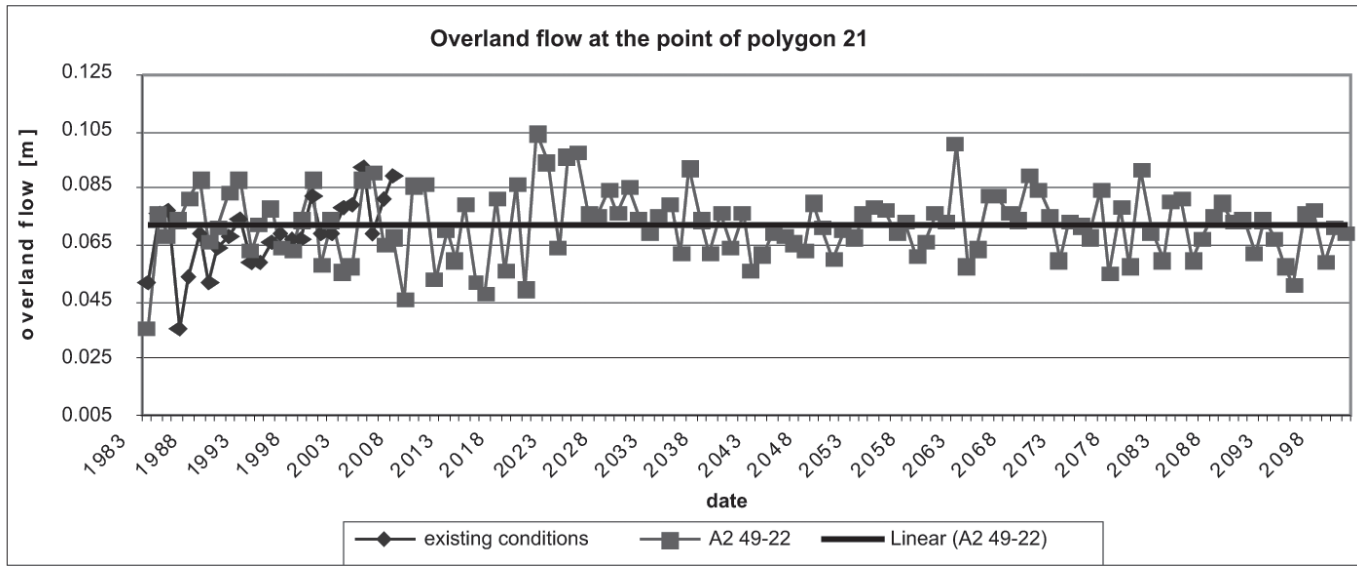

Fig. 15 Annual overland flow of the entire simulated period 1983-2100

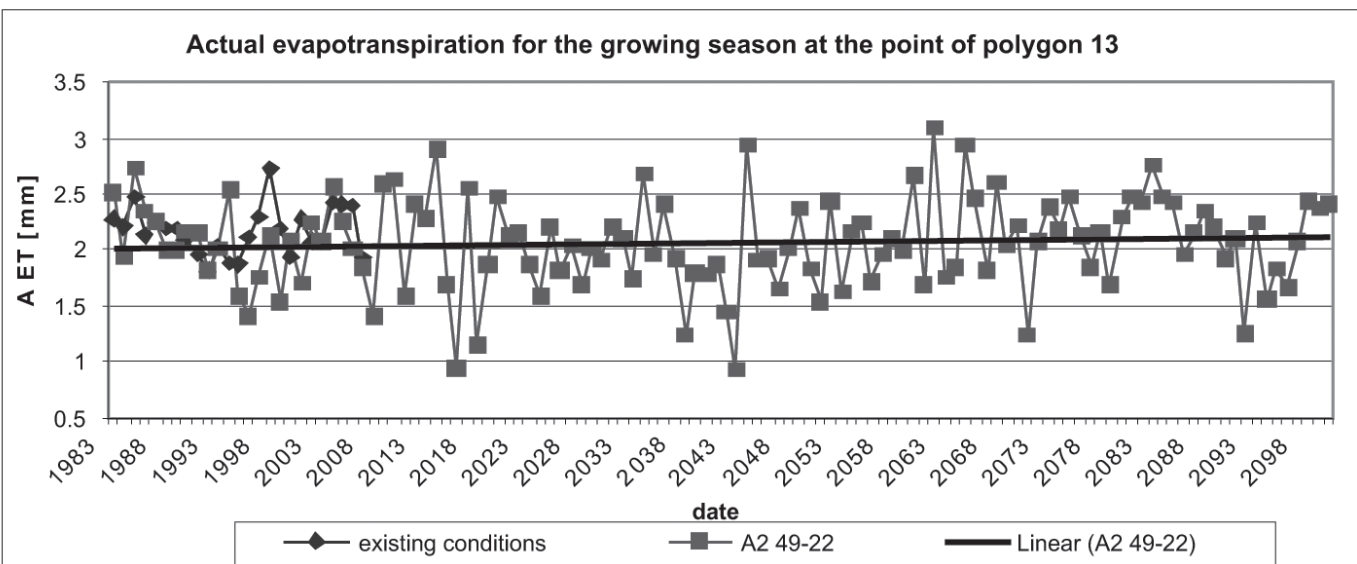

Fig. 16 Actual evapotranspiration for the growing season of the entire simulated period 1983-2100

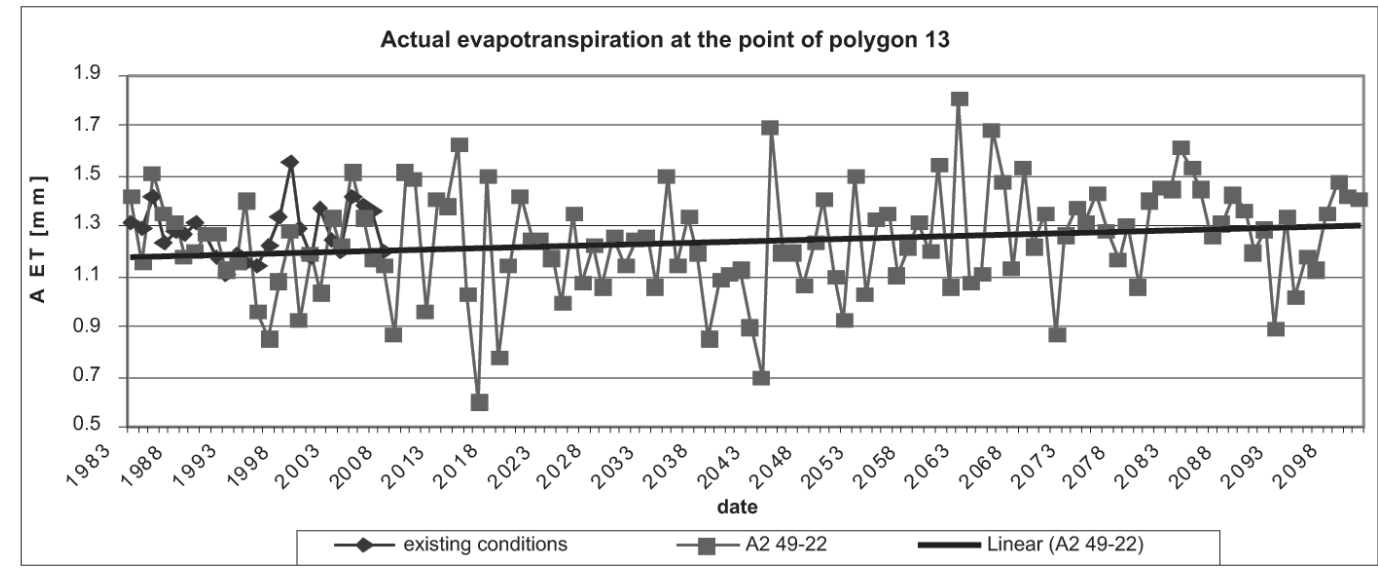

Fig. 17 Annual actual evapotranspiration of the entire simulated period 1983-2100 


\section{IDYHUSOOUSSLAL \\ Of $\mathrm{f}^{*}$

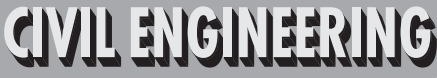

2010/4 PAGES $30-40$

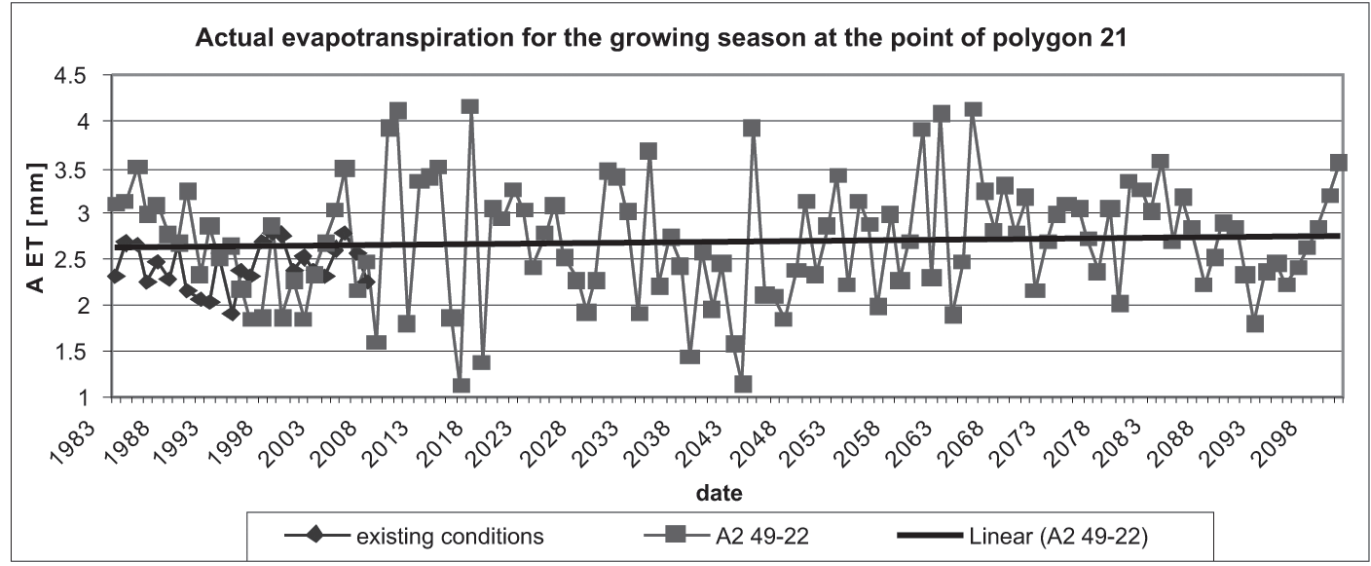

Fig. 18 Actual evapotranspiration for the growing season of the entire simulated period 1983-2100

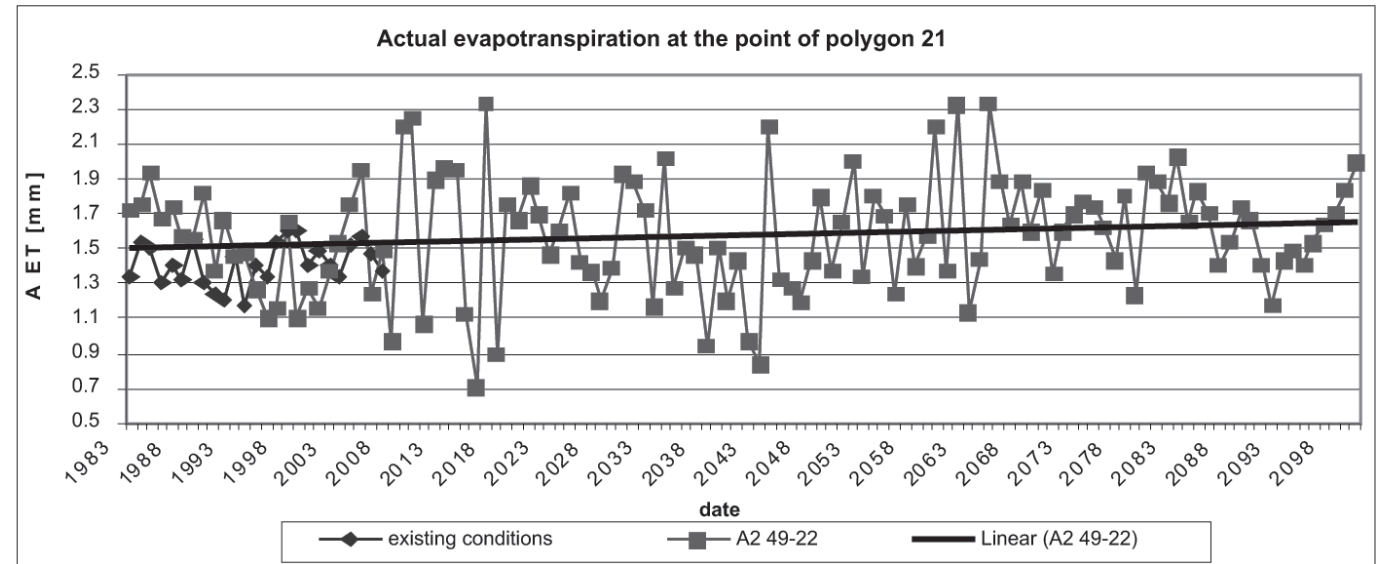

Fig. 19 Annual actual evapotranspiration of the entire simulated period 1983-2100

\subsection{Comparison of the existing and changed conditions (climate scenarios)}

The Mike SHE built-up model used for the existing conditions was also used for modeling the hydrological balance for the Senianska depression with a grid size of $1 \mathrm{x} 1$ meter for changed conditions - climate scenarios.

Pursuant to consultations with the project's partners, we focused on 30 polygons located in a pilot area (figure 11), which are important in terms of the vegetation conditions and for the total restoration of the wetland system in the modeled area.

In the article we provide the results of the overland flow and actual evapotranspiration for 1 point of the 2 polygons chosen -12 and 19 (see figure 11).
In the next figures we compare the outputs of the annual overland flow and overland flow for the growing season for the existing conditions for the simulation period 1983-2007 and the climate scenarios for the simulation period 1983-2100.

In the following figures we compare the outputs of the annual actual evapotranspiration and actual evapotranspiration for the growing season for the existing conditions for the simulation period 19832007 and the climate scenarios for the simulation period 19832100.

In figures $12-19$, there is a comparison of the annual overland flow and the annual evapotranspiration for the existing conditions and climate scenario (A2). We have simulated evapotranspiration and overland flow for the climate scenario for the period of years 19832100. Based on the trend line drawn in figures, we can assume that 
there will be a slight increasing of the annual evapotranspiration in the modeling area for future decades. The increasing of the average annual evapotranspiration overall, can cause drying in this area. Based on the trend line in figures showing the comparison of the annual overland flow for the existing conditions and the climate scenario, we can assume creating less overland flow in the simulated area for future decades. Overall the results for the scenarios show a slow decrease in the overland flow, what can cause less of groundwater in the modeling area in the future.

\section{CONCLUSION}

The Mike SHE built-up model with setting parameters was used for modeling the elements of the hydrological balance with an emphasis on creating the overland flow in the Senianska depression for the changed conditions - climate scenarios.

The aim of this article was to analyze the hydrological balance for future decades in the Senianska depression and compare the overland flow and actual evapotranspiration for the existing and changed conditions. Based on the comparison and overall analysis of the pilot area, the aim is to revitalize of wetland systems in the Senianska depression.

\section{Acknowledgement}

This article was written thanks to the support of the United Nations Development Programme (UNDP) project "Laborec-Uh" and the Slovak Research and Development Agency based on Contract Nod. APVV-0378-07 and LPP-0254-07.

\section{REFERENCES}

- Carter, V., 1986: An overview of the hydrologic concerns related to wetlands in the United States: Canadian Journal of Botany, no. $2,364-374$.

- Cowardin, L.M., Carter, V., Golet, F.C., Laroe, E.T., 1979: Classification of Wetlands and Deepwater Habitats of the United States, U.S. Fish and Wildlife Service Office of Biological Services FWS/OBS-79/31. pp. 1-103.

- DHI (Dánsky Hydrologický Inštitút), 2008: http://www. dhigroup.com/.

- Environmental Laboratory, 1987: Corps of Engineers Wetland Delineation Manual, Technical Report Y-87-1, US Army Engineers Waterways Experiment Station, Vicksburg, MS.

- Juráková M., Skalová J., 2005: Vodná bilancia mokrade Zelienka, Katedra vodného hospodárstva krajiny, Stavebná fakulta STU, Bratislava.

- Lapin, M., Damborská, I., Melo, M., Vojtek, M., Martini, M., 2006: Physicaly and statistically plausible downscaling of daily GCMs outputs and selected results. Acta Meteorologica Universitatis Comenianae, XXXIV, (2006), 35-57.
- Mitsch, W. J., Gosselink, J. G., 2000: Wetlands. Third Edition. John Wiley \& Sons, Inc., New York. 920 pp.

- Repka,1961:Správao prevedenomhydrogeologickom prieskume pre JRD Senné, okr. Michalovce, Krajský pol’nohospodársky projektový ústav v Košiciach, II-561/60-C-1.

- Silva-Hidalgo, H., Martín-Domínguez, I. R., Alarcón-Herrera, M. T., Granados-Olivas, A., 2008: Mathematical Modelling for the Integrated Management of Water Resources in Hydrological Basins, Springer Science + Business Media B.V.

- Skaggs, R.W. 1999: Drainage simulation models. pp. 461-492. In R.W. Skaggs, et al. (ed.) Agricultural drainage, Agron. Monogr. 38. ASA, CSSA, and SSSA, Madison, WI.

- S Sútor, J., Mati, R., Ivančo, J., Gomboš, M., Kupčo, M., Št’astný, P., 1995: Hydrológia Východoslovenskej nížiny, Media Group, v.o.s., Michalovce, ISBN 80-88835-00-3, 467pp.

- http://www.kosice.regionet.sk/KSKWeb/Cinnosti/ RegionalnyRozvoj/Projekty/200761214324767.htm,2009.m. 